\title{
Studies of Genetic Variability, Heritability and Genetic Gain for Some Important Horticultural Traits in Cauliflower (Brassica oleracea var. botrytis L.)
}

\author{
Subhrajyoti Chatterjee $^{1 *}$, Omkar Aralikatti ${ }^{2}$, Shweta Sharma $^{2}$, Debmala Mukherjee ${ }^{1}$, \\ Sumit Patil ${ }^{2}$, Hardyal Singh Kanwar ${ }^{2}$ and Partha Choudhuri ${ }^{1}$ \\ ${ }^{1}$ Department of Vegetable Crops, Bidhan Chandra Krishi Viswavidyalaya, Mohanpur, \\ Nadia- 741252, West Bengal, India \\ ${ }^{2}$ Department of Vegetable Science, Dr. YS Parmar University of Horticulture and Forestry, \\ Nauni, Solan- 173230, Himachal Pradesh, India \\ *Corresponding author
}

\begin{abstract}
A B S T R A C T
\end{abstract}
Twenty mid-late and late group cauliflower genotypes were evaluated during Rabi season

\section{Keywords}

Cauliflower,

Horticultural traits,

Genetic variability,

Heritability, Genetic gain

Article Info

Accepted:

04 March 2018

Available Online:

10 April 2018 of 2016 at the Experimental Farm of the Department of Vegetable Science, Dr. YS Parmar University of Horticulture and Forestry, Solan, Himachal Pradesh. The objective was to estimate the nature and magnitude of genetic variability, heritability and genetic gain of ten important horticultural traits. The magnitude of PCV was higher than the corresponding GCV for all the characters studied. Moderate estimates of GCV was recorded for leaf number per plant $(19.12 \%)$, curd depth $(15.76 \%)$, plant height $(20.85 \%)$, leaf size index (19.44\%), curd size index (26.51\%), gross weight per plant $(19.56 \%)$, and marketable yield per plant $(18.63 \%)$. High heritability $(>80 \%)$ coupled with high genetic gain $(>50 \%)$ was noted for the trait curd size index whereas high heritability coupled with moderate genetic gain was found in the traits like leaf number per plant, curd depth, leaf size index, gross weight per plant and marketable yield per plant. These indicated presence of sufficient variability in the germplasm, predominance of additive gene action and high transmissibility of the characters. So that, direct selection will be rewarding depending upon these traits.

\section{Introduction}

Cauliflower (Brassica oleracea var. botrytis L.), one of the members of the family Brassicaceae, follows cabbage in importance with regard to area and production in the world. However, in India cauliflower is more widely grown than cabbage and considered as the popular most 'cole' crop (Ram, 2012). It is one of the most widely grown vegetable crops in India especially during the winter months and commercially grown for its 'curd' which is a peculiar type of inflorescence consisting of thick, fleshy, strongly ramified flower stalks (Nieuwhof, 1969). Curds are used as sauted or fried vegetable either separately or with potato, peas, capsicum or other vegetables. It is also cooked in curry and 
sambhar (Swarup, 2006). India is the second largest producer of cauliflower in the world after China. In India, cauliflower is cultivated in an area of 452.13 thousand ha of land having a production of 8498.85 thousand tonnes. The productivity is $18.79 \mathrm{t} / \mathrm{ha}$ (NHB Database, 2017). But in terms of productivity, India is lagging far behind many countries viz., China, Spain and Italy. This gap in productivity can be corrected by developing high yielding cultivars (Garg and Lal, 2006).

Agronomic traits such as curd yield and its components are major selection criteria for increasing the productivity of cauliflower (Yanglem and Tumbare, 2014). The morphological characters of this crop although subjected to variation through environmental influences, are undoubtedly the best indicators of yield. Therefore, they have received a great attention (Santhosha et al., 2014).

Survey of genetic variability with the help of suitable parameters such as genotypic coefficient of variation, heritability estimates and genetic advance are absolutely necessary to start an efficient breeding program (Abebe et al., 2017) and the success of the programme depends upon the magnitude of these parameters (Meena and Bahadur, 2014). Phenotypic and genotypic coefficients of variation are helpful to estimate the magnitude of variability present in a population. Heritability of a character provides an idea of the extent of genetic control for the expression of a particular character (Priyanka et al., 2016).

Moreover, heritability serves as a guide to the reliability of phenotypic variability in the selection programme and hence determines its success. It is advocated that for effective selection, heritability along with genetic advance is more useful (Johnson et al., 1955). Genetic advance indicates the magnitude of the expected genetic gain from one cycle of selection. For improvement of cauliflower based on the magnitude of these parameters of variability, suitable breeding programme can be planned. Therefore, the present investigation was undertaken to evaluate variability, heritability and genetic advance of ten quantitative characters in twenty cauliflower genotypes to provide necessary information that could be useful to improve yield traits.

\section{Materials and Methods}

\section{Experimental site and environment}

The present study was conducted at the Experimental Farm of the Department of Vegetable Science, Dr. YS Parmar University of Horticulture and Forestry, Nauni, Solan in Himachal Pradesh, India during Rabi season of 2016. It is located at an altitude of about $1276 \mathrm{~m}$ above mean sea level, lying between $30^{\circ} 52^{\prime} 30^{\prime \prime} \mathrm{N}$ latitude and $77^{\circ} 11$ '30" $\mathrm{E}$ longitude under sub- humid, sub-temperate and mid hill zones of Himachal Pradesh. The mean temperature during the cropping season ranged from $10.8^{0} \mathrm{C}$ to $21.4^{0} \mathrm{C}$, while the relative humidity varied from $41.0 \%$ to $56.00 \%$. The total rainfall during the growing season was $161.30 \mathrm{~mm}$. The soil $\mathrm{pH}$ of Experimental Farm varied from 6.85 to 7.04 .

\section{Experimental material, layout and observations}

The experiment was laid out with three replications in a Randomized Complete Block Design and experimental materials comprised of twenty genotypes of mid late and late type cauliflower, collected from different parts of country and abroad (Table 1). The seed sowing of all the genotypes was carried out on September, 2016 in raised bed nursery. On $10^{\text {th }}$ October, the healthy seedlings were transplanted at a spacing of $60 \mathrm{~cm} \times 45 \mathrm{~cm}$ on individual plot size of $3 \mathrm{~m} \times 2.25 \mathrm{~m}$. Standard 
cultural practices recommended in the Package of Practices for Vegetable crops (Anonymous, 2013) were followed to ensure a healthy crop stand. The observations were recorded for different traits on ten randomly selected plants from each replication.

\section{Statistical analysis}

The statistical analysis for all the characters studied was done by the method recommended by Gomez and Gomez (1983) for Randomized Complete Block Design (RCBD).

Phenotypic and genotypic coefficient of variation (PCV and GCV)

PCV and GCV were calculated using the formulae suggested by Burton and De-Vane (1953).

\section{Phenotypic Coefficient of Variation (PCV)}

$\operatorname{PCV}(\%)=\frac{\sqrt{\text { Phenotypic variance }(\mathrm{Vp})}}{\text { General mean of population (GM) }} \times 100$

\section{Genotypic Coefficient of Variation (GCV)}

$\mathrm{GCV}(\%)=\frac{\sqrt{\text { Genotypic variance }(\mathrm{Vg})}}{\text { General mean of population (GM) }} \times 100$

Here, $\mathrm{V}_{\mathrm{p}}=\left(\mathrm{V}_{\mathrm{g}}+\mathrm{V}_{\mathrm{e}}\right)$ and $\mathrm{V}_{\mathrm{g}}=\left(\mathrm{M}_{\mathrm{t}}-\mathrm{M}_{\mathrm{e}}\right) / \mathrm{r}$. Where, $\mathrm{M}_{\mathrm{t}}=$ Treatment (genotype) mean square, $\mathrm{M}_{\mathrm{e}}=$ error mean square, $\mathrm{V}_{\mathrm{e}}=$ Environmental variation $=\mathrm{M}_{\mathrm{e}}$ and $\mathrm{r}=$ replication.

According to Sharma (1994), the estimates of PCV and GCV were classified as low $(<15 \%)$, moderate $(15-30 \%)$ and high $(>30 \%)$.

\section{Heritability}

Heritability in broad sense is calculated as per the method suggested by Allard (1960).
$\mathrm{H}^{2}{ }_{\mathrm{b}}=\frac{V g}{V p} \times 100$

The estimates were classified as low $(<50 \%)$, moderate $(50-80 \%)$ and high $(>80 \%)$ as suggested by Sharma (1994).

\section{Genetic advance}

The expected genetic advance (GA) was calculated as per the method suggested by Allard (1960), Genetic advance $(\mathrm{GA})=\mathrm{H}_{\mathrm{b}}{ }^{2} \times$ rp $\times \mathrm{K}$. Where, $\mathrm{H}_{\mathrm{b}}{ }_{\mathrm{b}}=$ Heritability in broad sense $(\%), \mathrm{rp}=$ Phenotypic standard deviation and $\mathrm{K}=2.06=$ Selection differential at $5 \%$ selection intensity.

\section{Genetic gain}

Genetic advance expressed as per cent of population mean was calculated by the formula suggested by Johnson et al., (1955).

Genetic gain $(\mathrm{GG})=(\mathrm{GA} / \mathrm{GM}) \times 100$. Where, $\mathrm{GG}=$ Genetic gain, $\mathrm{GA}=$ Genetic advance, $\mathrm{GM}=$ Population mean .

The estimates of genetic gain was classified as low $(<25 \%)$, moderate $(25-50 \%)$ and high $(>50 \%)$.

\section{Results and Discussion}

Analysis of variance presented in Table 2 indicated a significant difference in all the genotypes for all the traits studied. This indicated the existence of considerable variability for all characters studied among the genotypes. Hence, it offers a better scope for further improvement of breeding material by the selection of promising genotypes in cauliflower breeding programme. The mean performance of genotypes for various characters is presented in Table 3. The parameters of variability for different traits have been presented in Table 4. In the present 
findings, it was observed that PCV was higher than the corresponding GCV for all the traits and it might be due to interaction of the genotypes with the environment to some degree or other denoting environmental factors influencing the expression of these characters. Close correspondence between PCV and GCV for the characters implied their relative resistance to prevailing environmental variation (Roychowdhury and Tah, 2013).

\section{Parameters of variability}

Days to marketable curd maturity from date of transplanting

Significant variations for days to marketable maturity were observed among the genotypes under study (Table 3). The differences between the genotypes for this character ranged from 87.45 to 140.55 days with a mean of 116.54 days.

Tremendous variability with respect to this trait was also reported by Pandey and Naik (1991), Jindal and Thakur (2004), Garg and Lal (2006), Singh and Dogra (2011), and Kalia et al., (2014). PCV (14.93\%) and GCV $(13.02 \%)$ were found low for this trait. The estimates of these parameters are in line with the findings of Kumar (2002), Pathania (2003) and Sharma (2003). Further, the trait had moderate heritability $(76.06 \%)$ and low genetic gain $(23.39 \%)$ which is also reported by Thakur (1998) and Kumar (2002).

\section{Stalk length (cm)}

Genotypes exhibited significant differences for stalk length (Table 3). The differences between the genotypes for this character ranged from 4.39 to $6.04 \mathrm{~cm}$ with mean value of $5.20 \mathrm{~cm}$. Considerable variability regarding this trait was found and it was in line with the findings of Jamwal et al., (1992), Thakur (1998), Kumar (2002), Pathania (2003), Garg and Lal (2006), Sood et al., (2006), Mehra (2012), Singh and Dogra (2013) and Santhosha et al., (2014).Both PCV (10.26\%) and GCV (10.17\%) had low estimates which was also reported by Kumar (2002), Pathania (2003) and Sharma (2003) earlier. High heritability $(98.16 \%)$ and low genetic gain $(20.76 \%)$ were reported for this trait which is in line with the findings of Mahajan (1997), Thakur (1998) and Kumar (2002).

\section{Leaf number per plant}

Number of leaves per plant revealed significant differences among the various genotypes studied (Table 3). It ranged from 11.77 to 21.55 with general population mean of 15.91. A good amount of variability regarding this trait was also reported by Jamwal et al., (1992), Thakur (1998), Kumar (2002), Garg and Lal (2006), Sharma (2006), Sood et al., (2006), Ahirwar et al., (2013), Santhosha et al., (2014) and Chittora and Singh (2015). Modrate estimates of PCV $(20.03 \%)$ and GCV (19.12\%) were found. Previously, Kumar (2002), Sood et al., (2006) and Mehra (2012) also found similar estimates. High heritability $(91.51 \%)$ and moderate genetic gain $(37.61 \%)$ were found for this trait which is also like the findings of Kumar (2002) and Pathania (2003).

\section{Gross weight per plant (g)}

A wide range of variability was recorded for gross curd weight among the twenty genotypes (Table 3). The range varied from $706.33 \mathrm{~g}$ to $1761.33 \mathrm{~g}$ with mean value of $1293.42 \mathrm{~g}$. Tremendous variability among the genotypes regarding the traits was also reported by Pandey and Naik (1991), Jamwal et al., (1992), Khar et al., (1997), Thakur (1998), Alaksh (2003), Jindal and Thakur (2004), Sood et al., (2006), Singh and Dogra (2013), Santhosha et al., (2014), Chittora and Singh (2015). 
Table.1 List of cauliflower genotypes along with their sources

\begin{tabular}{|l|l|l|}
\hline Sr no & Genotype & Source \\
\hline 1. & UHF-C-2 & Dr YSPUHF, Nauni, Solan \\
\hline $\mathbf{2 .}$ & Palam Uphar & CSKHPKV, Palampur \\
\hline $\mathbf{3 .}$ & King King & HRI, Wellesbourne, UK \\
\hline 4. & Pusa Himjyoti & IARI, Katrain \\
\hline 5. & EC-683466 & NBPGR, New Delhi \\
\hline $\mathbf{6 .}$ & EC-683461 & NBPGR, New Delhi \\
\hline $\mathbf{7 .}$ & EC-162587 & NBPGR, New Delhi \\
\hline $\mathbf{8 .}$ & Hermia & HRI, Wellesbourne, UK \\
\hline $\mathbf{9 .}$ & Kt-18 & IARI, Katrain \\
\hline 10. & Kt-25 & IARI, Katrain \\
\hline 11. & Kt-19 & IARI, Katrain \\
\hline 12. & Kt-20 & IARI, Katrain \\
\hline 13. & Kt-22 & IARI, Katrain \\
\hline 14. & Mukutamani & IARI, Katrain \\
\hline 15. & Sel-I & Dr YSPUHF, Nauni, Solan \\
\hline 16. & Sel-II & Dr YSPUHF, Nauni, Solan \\
\hline 17. & DC-76 & IARI, New Delhi \\
\hline 18. & Pant Shubhra & GBPUAT, Pantnagar, Uttarakhand \\
\hline 19. & Snowball-16 & IARI, Katrain \\
\hline 20. & PSBK-I (Check) & IARI, Katrain \\
\hline
\end{tabular}

Table.2 Analysis of variance for various horticultural traits in cauliflower

\begin{tabular}{|c|c|c|c|c|c|c|c|c|c|c|c|}
\hline Character & df & & & & Me & an Sum of $\mathrm{Sc}$ & uares & & & & \\
\hline Source & & $\begin{array}{c}\text { Days to } \\
\text { marketable } \\
\text { curd maturity } \\
\text { from date of } \\
\text { transplanting }\end{array}$ & $\begin{array}{l}\text { Stalk } \\
\text { length } \\
(\mathrm{cm})\end{array}$ & $\begin{array}{c}\text { Leaf } \\
\text { number per } \\
\text { plant }\end{array}$ & $\begin{array}{c}\text { Gross } \\
\text { weight per } \\
\text { plant (g) }\end{array}$ & $\begin{array}{c}\text { Marketable } \\
\text { yield per } \\
\text { plant (g) }\end{array}$ & $\begin{array}{l}\text { Curd } \\
\text { depth } \\
(\mathrm{cm})\end{array}$ & $\begin{array}{l}\text { Plant } \\
\text { height } \\
(\mathrm{cm})\end{array}$ & $\begin{array}{c}\text { Leaf size } \\
\text { index }\left(\mathrm{cm}^{2}\right)\end{array}$ & $\begin{array}{l}\text { Curd size } \\
\text { ndex }\left(\mathrm{cm}^{2}\right)\end{array}$ & $\begin{array}{c}\text { Curd } \\
\text { solidity } \\
(\mathrm{g} / \mathrm{cm})\end{array}$ \\
\hline Replication & 2 & 37.642 & 0.0005 & 0.045 & 756.597 & 24.695 & 0.056 & 8.058 & 3495.076 & 31.178 & 7.462 \\
\hline Treatment & 19 & $763.430^{*}$ & $0.846^{*}$ & $28.683^{*}$ & 193530.799* & $53334.959 *$ & $7.147^{*}$ & $166.737 *$ & $84636.601 *$ & $1790.76^{*}$ & 293.432* \\
\hline Error & 38 & 72.460 & 0.005 & 0.899 & 1386.80 & 151.522 & 0.370 & 33.808 & 2897.683 & 67.79 & 24.911 \\
\hline
\end{tabular}

* Significant at $5 \%$ level of significance 
Table.3 Mean performance of 20 genotypes of cauliflower for different horticultural traits

\begin{tabular}{|c|c|c|c|c|c|c|c|c|c|c|c|}
\hline $\begin{array}{l}\text { S. } \\
\text { No. }\end{array}$ & Genotypes & $\begin{array}{c}\text { Days to } \\
\text { marketable } \\
\text { curd maturity } \\
\text { from date of } \\
\text { transplanting }\end{array}$ & $\begin{array}{c}\text { Stalk } \\
\text { length } \\
(\mathrm{cm})\end{array}$ & $\begin{array}{c}\text { Leaf } \\
\text { number } \\
\text { per } \\
\text { plant }\end{array}$ & $\begin{array}{c}\text { Gross } \\
\text { weight per } \\
\text { plant (g) }\end{array}$ & $\begin{array}{c}\text { Marketable } \\
\text { yield per } \\
\text { plant (g) }\end{array}$ & $\begin{array}{c}\text { Curd } \\
\text { depth }(\mathrm{cm})\end{array}$ & $\begin{array}{l}\text { Plant height } \\
(\mathrm{cm})\end{array}$ & $\begin{array}{l}\text { Leaf } \\
\text { size } \\
\text { index } \\
\left(\mathrm{cm}^{2}\right)\end{array}$ & $\begin{array}{l}\text { Curd } \\
\text { size } \\
\text { index } \\
\left(\mathrm{cm}^{2}\right)\end{array}$ & $\begin{array}{l}\text { Curd } \\
\text { solidity } \\
(\mathrm{g} / \mathrm{cm})\end{array}$ \\
\hline 1. & UHF-C-2 & 120.02 & 4.96 & 14.33 & 1301.67 & 755.67 & 9.18 & 54.72 & 968.71 & 140.45 & 82.42 \\
\hline 2. & Palam Uphar & 109.08 & 4.81 & 14.22 & 1251.60 & 701.67 & 8.48 & 44.35 & 1003.54 & 138.17 & 82.83 \\
\hline 3. & King King & 114.97 & 4.78 & 12.66 & 1277.93 & 707.33 & 9.27 & 43.86 & 999.65 & 139.33 & 76.33 \\
\hline 4. & Pusa Himjyoti & 121.77 & 5.05 & 15.22 & 1306.47 & 759.33 & 10.27 & 54.41 & 735.34 & 144.37 & 73.97 \\
\hline 5. & EC-683466 & 137.95 & 5.90 & 17.99 & 1711.67 & 890.33 & 10.01 & 51.13 & 636.02 & 176.74 & 89.59 \\
\hline 6. & EC-683461 & 100.83 & 4.86 & 15.33 & 1176.67 & 546.27 & 8.24 & 36.85 & 1006.38 & 111.32 & 66.34 \\
\hline 7. & EC-162587 & 129.59 & 5.16 & 15.44 & 1456.67 & 824.87 & 10.62 & 43.76 & 683.91 & 182.42 & 78.27 \\
\hline 8. & Hermia & 140.55 & 6.04 & 21.55 & 1761.33 & 906.67 & 12.09 & 55.88 & 587.26 & 177.37 & 74.99 \\
\hline 9. & Kt-18 & 112.81 & 5.04 & 15.11 & 1273.67 & 704.93 & 9.68 & 49.89 & 1003.33 & 138.97 & 73.15 \\
\hline 10. & $\mathrm{Kt}-25$ & 111.85 & 6.02 & 20.88 & 1253.33 & 703.00 & 10.96 & 41.64 & 1003.45 & 138.79 & 64.20 \\
\hline 11. & Kt-19 & 124.77 & 6.00 & 20.55 & 1337.33 & 766.93 & 9.59 & 42.37 & 734.49 & 146.71 & 80.31 \\
\hline 12. & $\mathrm{Kt}-20$ & 93.47 & 4.69 & 11.99 & 953.00 & 526.93 & 7.58 & 38.95 & 1020.33 & 103.29 & 69.60 \\
\hline 13. & Kt-22 & 87.45 & 5.89 & 19.44 & 940.33 & 509.40 & 8.25 & 34.78 & 1022.15 & 110.14 & 61.78 \\
\hline 14. & Mukutamani & 87.89 & 4.39 & 11.77 & 706.33 & 457.33 & 7.81 & 36.52 & 1027.18 & 117.13 & 58.65 \\
\hline 15. & Sel-I & 126.77 & 4.86 & 12.99 & 1344.67 & 767.53 & 9.02 & 54.61 & 687.27 & 153.63 & 85.25 \\
\hline 16. & Sel-II & 131.71 & 4.70 & 12.33 & 1540.00 & 846.67 & 12.09 & 52.13 & 662.74 & 168.85 & 70.15 \\
\hline 17. & DC-76 & 100.62 & 5.82 & 19.44 & 1054.33 & 531.60 & 7.88 & 39.60 & 1011.11 & 113.48 & 67.62 \\
\hline 18. & Pant Shubhra & 134.54 & 5.13 & 16.22 & 1572.00 & 857.53 & 12.82 & 51.17 & 633.57 & 180.29 & 67.30 \\
\hline 19. & Snowball-16 & 120.08 & 4.80 & 14.32 & 1323.39 & 762.29 & 7.95 & 53.49 & 778.88 & 143.44 & 95.92 \\
\hline 20. & PSBK-I (Check) & 124.17 & 5.12 & 16.44 & 1326.00 & 766.53 & 8.86 & 54.51 & 771.58 & 145.93 & 86.95 \\
\hline & Mean & 116.54 & 5.20 & 15.91 & 1293.42 & 714.64 & 9.53 & 46.73 & 848.84 & 143.54 & 75.28 \\
\hline & $\mathrm{SE}(\mathrm{m}) \pm$ & 4.91 & 0.04 & 0.54 & 21.50 & 7.10 & 0.35 & 1.57 & 31.07 & 4.75 & 2.88 \\
\hline & C.V. & 7.30 & 1.39 & 5.95 & 2.87 & 1.72 & 6.38 & 12.36 & 6.34 & 5.73 & 6.63 \\
\hline & CD at $5 \%$ & 14.12 & 0.12 & 1.57 & 61.79 & 20.42 & 1.01 & 9.64 & 89.32 & 13.66 & 8.28 \\
\hline
\end{tabular}


Table.4 Estimates of population mean range, phenotypic and genotypic coefficients of variability, heritability, genetic advance and genetic gain

\begin{tabular}{|c|c|c|c|c|c|c|c|c|}
\hline \multirow[t]{2}{*}{ Characters } & \multirow{2}{*}{$\begin{array}{l}\text { Population } \\
\text { mean }\end{array}$} & \multicolumn{2}{|c|}{ Range } & \multicolumn{2}{|c|}{ Coefficient of variability } & \multirow{2}{*}{$\begin{array}{l}\text { Heritability } \\
\text { Broad sense } \\
\qquad \%)\end{array}$} & \multirow{2}{*}{$\begin{array}{l}\text { Genetic } \\
\text { advance }\end{array}$} & \multirow{2}{*}{$\begin{array}{l}\text { Genetic } \\
\text { gain }(\%)\end{array}$} \\
\hline & & Minimum & Maximum & Phenotypic & Genotypic & & & \\
\hline $\begin{array}{c}\text { Days to marketable curd } \\
\text { maturity from date of } \\
\text { transplanting } \\
\end{array}$ & 116.54 & 87.45 & 140.55 & 14.93 & 13.02 & 76.06 & 27.26 & 23.39 \\
\hline Stalk length $(\mathrm{cm})$ & 5.201 & 4.39 & 6.04 & 10.26 & 10.17 & 98.16 & 1.08 & 20.76 \\
\hline Number of leaves & 15.91 & 11.77 & 21.55 & 20.03 & 19.12 & 91.51 & 5.98 & 37.61 \\
\hline Gross weight per plant (g) & 1293.42 & 706.33 & 1761.33 & 19.77 & 19.56 & 97.88 & 515.78 & 39.87 \\
\hline $\begin{array}{c}\text { Marketable yield per plant } \\
(\mathrm{g})\end{array}$ & 714.64 & 457.33 & 906.67 & 18.71 & 18.63 & 99.15 & 273.11 & 38.21 \\
\hline Curd depth $(\mathrm{cm})$ & 9.53 & 7.58 & 12.82 & 17.01 & 15.76 & 85.91 & 2.87 & 30.10 \\
\hline Plant height (cm) & 46.73 & 34.78 & 55.88 & 24.60 & 20.85 & 71.84 & 18.41 & 36.41 \\
\hline Leaf size index $\left(\mathrm{cm}^{2}\right)$ & 848.84 & 587.26 & 1027.18 & 20.45 & 19.44 & 90.38 & 323.28 & 38.08 \\
\hline Curd size index $\left(\mathrm{cm}^{2}\right)$ & 143.54 & 103.29 & 182.42 & 27.06 & 26.51 & 95.99 & 79.40 & 53.51 \\
\hline Curd solidity (g/cm) & 75.28 & 58.65 & 95.92 & 14.20 & 12.56 & 78.22 & 17.23 & 22.89 \\
\hline
\end{tabular}


Moderate values of PCV (19.77\%) and GCV $(19.56 \%)$ along with high heritability $(97.88 \%)$ and moderate genetic gain $(39.87 \%)$ were found regarding this trait which is in line with the findings of Kumar (2002) and Pathania (2003).

\section{Marketable yield per plant (g)}

Marketable yield per plant varied from 457.33 $\mathrm{g}$ to $906.67 \mathrm{~g}$. General population mean was found to be $714.64 \mathrm{~g}$ (Table 3). Significant variability regarding this trait among the genotypes was also suggested by Pandey and Naik (1991), Jamwal (1992), Bharadwaj and Sharma (1996), Khar et al., (1997), Thakur (1998), Pathania (2003), Jindal and Thakur (2004), Sood et al., (2006), Singh and Dogra (2013), Santhosha et al., (2014), Chittora and Singh (2015). Moderate values of PCV $(18.71 \%)$ and GCV (18.63\%) along with high heritability $(99.15 \%)$ and moderate genetic gain $(38.21 \%)$ were found regarding this trait which is in line with the findings of Kumar (2002) and Pathania (2003).

\section{Curd depth (cm)}

Data pertaining to this trait revealed significant variations among genotypes (Table 3). Curd depth ranged from $7.58 \mathrm{~cm}$ to 12.82 $\mathrm{cm}$ with a general population mean of 9.53 $\mathrm{cm}$. Significant variability regarding this trait among the genotypes also reported by Jamwal et al., (1992), Thakur (1998), Kumar (2002), Pathania (2003), Sharma (2006) and Chittora and Singh (2015). This trait had moderate PCV (17.01\%) as well as GCV (15.76) along with high heritability $(85.91 \%)$ and moderate genetic gain $(30.10 \%)$. These estimates are in accordance with Sharma (2006).

\section{Plant height (cm)}

Plant height varied from $34.78 \mathrm{~cm}$ to 55.88 $\mathrm{cm}$. The population mean was $46.73 \mathrm{~cm}$
(Table 3). A significant amount of variability among the genotypes regarding the trait under study was found and the same result was also found by Jindal and Thakur (2004), Ahirwar et al., (2013), Singh et al., (2013), Kalia et al., (2014), Chittora and Singh (2015). Moderate estimates of PCV (24.60\%) and GCV $(20.85 \%)$ were recorded regarding this trait. Further moderate heritability $(71.84 \%)$ along with moderate genetic gain $(36.41 \%)$ was recorded.

\section{Leaf size index $\left(\mathrm{cm}^{2}\right)$}

Leaf size index ranged from $587.26 \mathrm{~cm}^{2}$ to $1027.18 \mathrm{~cm}^{2}$ with a general population mean of $848.84 \mathrm{~cm}^{2}$ (Table 3). High variability regarding the trait among all the genotypes has been found which was in line with the findings of Sharma (2006). Moderate values of PCV (20.45\%) and GCV (19.44\%) along with high heritability $(90.38 \%)$ and moderate genetic gain $(38.08 \%)$ were found. Sharma (2006) earlier also suggested similar types of result except genetic gain, which was reported to be low.

\section{Curd size index $\left(\mathrm{cm}^{2}\right)$}

Significant variations for curd size index were observed among the genotypes under study (Table 3). The differences between the genotypes for this character ranged from $103.29 \mathrm{~cm}^{2}$ to $182.42 \mathrm{~cm}^{2}$ with a general population mean of $143.54 \mathrm{~cm}^{2}$. High variability regarding the trait among all the genotypes has been found which was in line with the findings of Garg and Lal (2006), Sood et al., (2006), Mehra (2012) and Chittora and Singh (2015). Both PCV $(27.06 \%)$ and GCV $(26.51 \%)$ were found to have moderate values. Further this trait had high heritability (95.99\%) and high genetic gain $(53.51 \%)$. Similar types of result previously suggested by Pathania (2003) and Sharma (2006). 


\section{Curd solidity (g/cm)}

Data pertaining to this trait revealed significant variations among genotypes (Table 3). Curd solidity ranged from $58.65 \mathrm{~g} / \mathrm{cm}$ to $95.92 \mathrm{~g} / \mathrm{cm}$. The population mean was found to be $75.28 \mathrm{~g} / \mathrm{cm}$. High variability regarding the trait among all the genotypes has been found which was in line with the findings of Jamwal et al., (1992), Thakur (1998) and Garg and Lal (2006). This trait was found to have low PCV (14.20\%) as well as GCV $(12.56 \%)$ along with moderate heritability (78.22\%) and low genetic gain (22.89\%).

High heritability along with moderate to high genetic advance as per cent of mean (genetic gain) in the characters like curd size index (high heritability with high genetic gain) and gross weight per plant, marketable yield per plant, leaf number per plant, leaf size index and curd depth (high heritability with moderate genetic gain) indicated the occurrence of additive gene action and hence selection as such may be effective for improvement of this trait. Stalk length had high heritability coupled with low genetic gain indicated the prevalence of non-additive gene interaction whereas plant height had moderate heritability along with moderate genetic gain so this trait can be improved through heterosis breeding. The traits like days to marketable curd maturity from date of transplanting and curd solidity had moderate heritability along with low genetic gain indicated the prevalence of dominance and epistatic effect hence selection for this trait might not be possible (Panse, 1957).

\section{Acknowledgements}

The author wants to acknowledge all the faculty members of Department of Vegetable Science, Dr YS Parmar University of Horticulture and Forestry, Nauni, Solan, Himachal Pradesh and ICAR for providing
NTS (National Talent Scholarship) during the study period.

\section{References}

Abebe, T., Alamerew, S. and Tulu, L. 2017. Genetic Variability, Heritability and Genetic Advance for Yield and its Related Traits in Rainfed Lowland Rice (Oryza sativa L.) Genotypes at Fogera and Pawe, Ethiopia. Adv. Crop. Sci. Tech. 5: 272.

Ahirwar, C., Prasad, V.M. and Yadav, M. 2013. Varietal evaluation of cauliflower (Brassica oleracea var. botrytis L.) in Allahabad agro climatic condition. Trends in Biosciences. 6(1): 99-100.

Allard, R.W. 1960. Principles of Plant Breeding. J. Wiley and Sons Inc. New York. p 485.

Anonymous, 2013. Package of Practices for Vegetable Crops. Directorate of Extension Education, Dr. YS Parmar University of Horticulture and Forestry, Nauni, Solan. p.124.

Anonymous, 2017. Indian Horticulture Database. National Horticulture Board. Gurgaon, Haryana. Pp. 202-203.

Burton, G.W. and De Vane, E.H. 1953. Estimating heritability in tall fescue (Festuca arundinaceae) from replicated clonal material. Proejtunniens. 9(22):12-15.

Chittora, A. and Singh, D.K. 2015. Genetic variability studies in early cauliflower (Brassica oleracea var. botrytis). Electronic Journal of Plant Breeding. 6(3): 842-847.

Garg, N. and Lal, T. 2006. Studies on standardized potence and gene action in cauliflower. Crop Improvement. 33(2): 98-101.

Gomez, K.A. and Gomez, A.A. 1983. Statistical Procedures for Agricultural Research. J. Wiley and Sons Inc. New York. Pp. 357-427. 
Jamwal, R.S., Prakash, S. and Bhardwaj, C.L. 1992. Evaluation of economic characters for breeding programme in late group of cauliflower (Brassica oleracea var. botrytis L.). Indian J. Agric. Sci. 62(6): 369-372.

Jindal, S.K. and Thakur, J.C. 2004. Variability studies in November maturity group of cauliflower (Brassica oleracea var. botrytis L.). Haryana J. Hort. Sci. 33(1\&2): 100-101.

Johnson, H.W., Robinson, H.F. and Comstock, R.E. 1955. Genotypic and phenotypic correlation in soyabean and their implication in selection. Agronomic J. 47:477-483.

Kalia, P., Bhatia, R., Prakash, C., Dey, S.S. and Barwal, R.N. 2014. Evaluation of cauliflower (Brassica oleracea var. botrytis L.) CMS (Ogura) lines for agronomic and floral traits. Indian $\mathrm{J}$. Hort. 71(3): 424-427.

Khar, A., Pathania, N.K., Saini, N. and Saini, N. 1997. Variability and heritability studies in late cauliflower. Annals of Biology. 13(1): 127-130.

Kumar, A. 2002. Genetic evaluation of some genotypes of cauliflower (Brassica oleracea var. botrytis L.). M.Sc. Thesis, Dr Y S Parmar University of Horticulture and Forestry, Solan, India.

Mahajan, V. and Gill, H. 1997. Studies on genetic variability, genetic advances and coefficient of variation in cauliflower. J. Maharashtra Agric. Uni. 22.1: 99-101.

Meena, O.P. and Bahadur, V. 2014. Assessment of genetic variability, heritability, and genetic advance among tomato (Solanum lycopersicum L.) germplasm. The Bioscan. 9(4): 16191623.

Mehra, D. 2012. Heterosis, combining ability and gene action studies in early cauliflower (Brassica oleracea var. botrytis L.). Ph.D. Thesis, G B Pant
University of Agriculture and Technology, Pantnagar, India.

Nieuwhof, M. 1969. Cole Crops. Leonard Hill, London, Pp. 57-58.

Pandey, S.C. and Naik, G. 1991. Genetics and character association studies in biparental progenies of cauliflower. Indian J. Hortic. 48: 351-355.

Panse, V.G. 1957. Genetics of quantitative characters in relation to plant breeding. Indian Journal of Genetics. 17: 318-328.

Pathania, A. 2003. Evaluation of cauliflower genotypes for horticultural traits and resistance to some diseases and insect pests. M.Sc. Thesis, Dr. YS Parmar University of Horticulture and forestry, Solan, India.

Priyanka, S., Rangaiah, S. and Showkath Babu, B.M. 2016. Genetic variability estimates of quantitative and qualitative traits in black gram. International Journal of Agriculture Sciences. 8(40): 1821-1824.

Ram, H.H. 2012. Cauliflower In: Vegetable Breeding Principles and Practices (Eds.) Ram, H.H, Kalyani Publishers, New Delhi, Pp. 474-491.

Roy chowdhury, R. and Tah, J. 2013. Mutagenesis- A Potential Approach for Crop Improvement In: Crop Improvement (Eds.) Hakeem, K. R., Ahmed, P. And Oztark, M. Springer, New York. Pp. 149-188.

Santosha, H.M., Varalakshmi, B. and Shivashankara, $\quad$ K.S. 2014. Characterization of early cauliflower germplasm under tropical conditions. The Bioscan. 9(2): 869-874.

Sharma, K. 2006. Genetic variability studies of some genotypes of cauliflower (Brassica oleracea var. botrytis L.). M.Sc. Thesis, Dr YS Parmar University of Horticulture and Forestry, Solan, India.

Sharma, P. 1994. Genetic variability and path coefficient analysis in cabbage 
(Brassica oleracea var. capitata). M.Sc. Thesis, Dr YS Parmar University of Horticulture and Forestry, Solan, India.

Singh, S.P. and Dogra, R.K. 2013. Studies on character association in some genotypes of cauliflower under mid hill conditions of western Himalaya. The Asian Journal of Horiculture. 8(1): 29-31.

Sood, S., Sharma, S., Pathak, S. and Sharma, A. 2006. Genetic variability for curd yield and its component traits in cauliflower (Brassica oleracea var. botrytis) under high hills dry temperate conditions. Veg. Sci. 33(1): 82-84.
Swarup, V. 2006. Vegetable Science and Technology in India, Kalyani Publishers, New Delhi, p.359.

Thakur, B.S. 1998. Breeding for resistance against black rot and heterosis studies in cauliflower (Brassica oleracea var. botrytis L.). Ph.D. Thesis. Dr YS Parmar University of Horticulture and Forestry, Solan, India.

Yanglem, S.D. and Tumbare, A.D. 2014. Influence of irrigation regimes and fertigation levels on yield and physiological parameters in cauliflower. The Bioscan. 9(2): 589-594.

\section{How to cite this article:}

Subhrajyoti Chatterjee, Omkar Aralikatti, Shweta Sharma, Debmala Mukherjee, Sumit Patil, Hardyal Singh Kanwar and Partha Choudhuri. 2018. Studies of Genetic Variability, Heritability and Genetic Gain for Some Important Horticultural Traits in Cauliflower (Brassica oleracea var. botrytis L.). Int.J.Curr.Microbiol.App.Sci. 7(04): 82-92.

doi: https://doi.org/10.20546/ijcmas.2018.704.010 